\title{
Preliminary observations on the Sumatran rhino in Way Kambas National Park, Indonesia
}

\author{
Joanne Reilly, Guy Hills Spedding and Apriawan
}

\begin{abstract}
The Sumatran rhino Dicerorhinus sumatrensis is regarded as critically endangered with a world population of approximately 400. In 1991 it was recorded in Way Kambas National Park, Sumatra, Indonesia, 30 years after the park's last rhino was believed to have been shot. A Sumatran Rhino Population and Habitat Viability Analysis (PHVA) workshop in 1993 recommended an immediate survey be carried out to assess the rhino population in the park. The Way Kambas Project recorded observations of rhino sign between 1993 and 1995. Sign was most frequently observed along trails in mature secondary forest. Data from the areas surveyed suggest the presence of at least four rhinos.
\end{abstract}

\section{Introduction}

The Sumatran rhinoceros Dicerorhinus sumatrensis, which was formerly widespread throughout South East Asia, is now restricted to Sumatra, Peninsular Malaysia, Malaysian Borneo, Kalimantan and possibly Vietnam, Laos, Thailand and Myanmar. An assessment of the Sumatran rhino population undertaken during a Population and Habitat Viability Analysis workshop in November 1993, which was sponsored by IUCN and the Indonesian Directorate General for Nature Preservation and Forest Protection (PHPA), estimated that the rhino population in Sumatra was approximately 50 per cent less than previous estimates (Siswomartono et al., 1996). In Sumatra, between 200 and 250 rhinos survive in approximately 10 locations, with the largest populations in the national parks of Gunung Leuser, Kerinci Seblat and Bukit Barisan Seletan.

International trade in all rhino parts, products and derivatives has been banned under the Convention on International Trade in Endangered Species since 1977 (Flynn and Abdullah, 1983), but the main threat to rhino survival is poaching for horn, which can sell at $\$ U S 2000$ per $\mathrm{kg}$ locally and up to $\$ \mathrm{US} 18,000$ per $\mathrm{kg}$ in Taiwan (Soemarna et al., 1994). The 1994 IUCN Red List of Threatened Animals classifies the Sumatran rhino as critically endangered and 'facing a very high probability of extinction in the wild in the immediate future' (Groombridge, 1993).

The history of rhinos in Way Kambas National Park is unclear. In 1961 the supposed last rhino was shot in the park and was believed to be a Javan rhino Rhinoceros sondaicus (Wind et al., 1979). The second horn of the Sumatran rhino is often unpronounced and was probably overlooked in the identification of this animal. Subsequent studies in the park concluded rhinos to be locally extinct (Borner, 1979 in Van Strien, 1985; Wind et al., 1979). However, in the 1980s rhino dung was recorded in the park and in 1991 park guards saw a rhino on the banks of the Way Kanan River (W. Ramono, pers. comm.). In July 1993 a cast from an observed print was confirmed as that of a Sumatran rhino (N. Van Strien, pers. comm.). A substantial amount of rhino sign was subsequently observed by the Way Kambas 1993 expedition from Trinity College Dublin and Southampton University. Plaster casts of rhino prints taken by this team were confirmed as belonging to the Sumatran rhino (N. Van Strien, pers. comm.). 


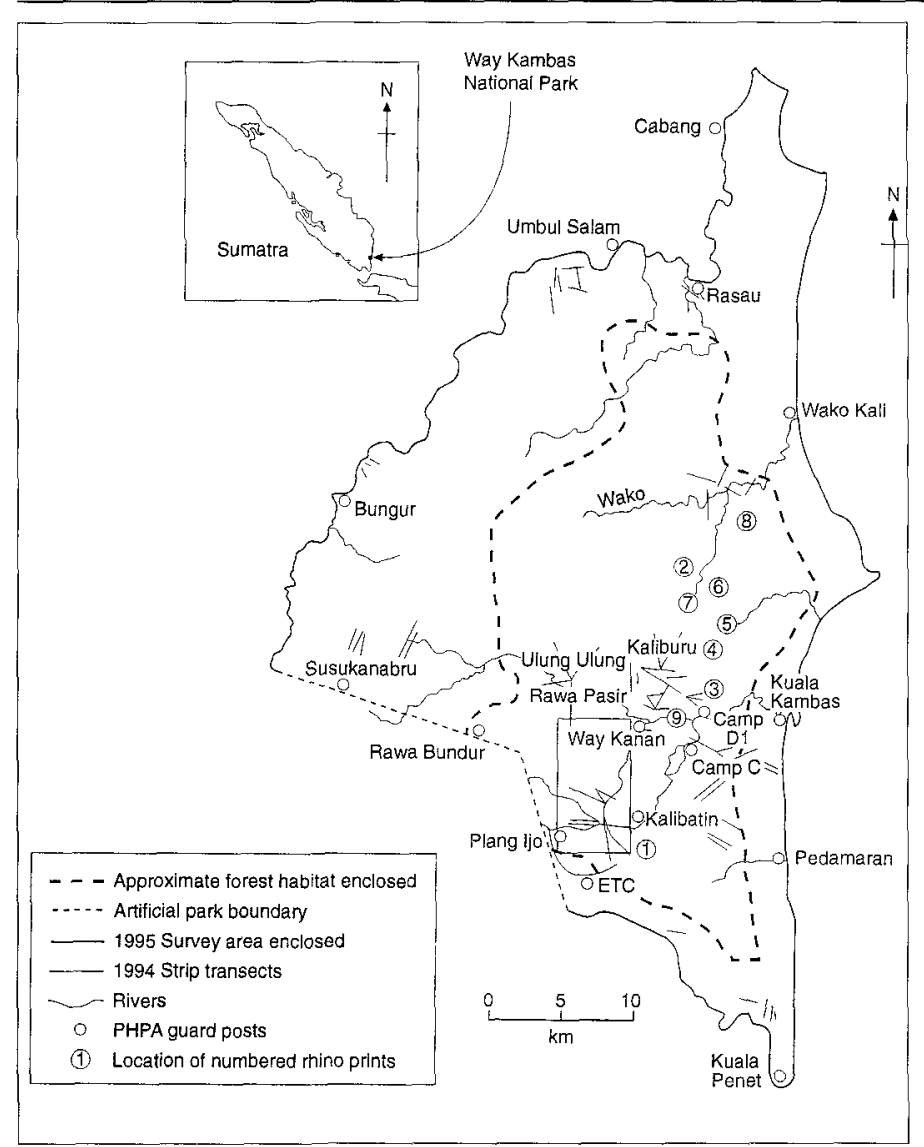

Figure 1. Map of Way Kambas National Park showing places mentioned in the text, rivers, location of numbered rhino prints, survey routes covered in 1994 and survey area covered in 1995.

The Way Kambas National Park covers 1235 sq $\mathrm{km}$ of low-lying coastal land in south-east Sumatra and is considered to be the flagship reserve for the Asian elephant Elephas maximus in Indonesia. It is bordered by natural boundaries, except for $28.5 \mathrm{~km}$ in the south-west (Figure 1). There is no buffer zone separating the park from the surrounding communities. Widespread logging from 1968 to 1974 and frequent burning has helped sustain many different habitat types. There are large tracts of Imperata cylindrica (alang alang) grassland in the park, which is of limited use for the rhino population (Van Strien, 1985).

\section{Methodology}

There were three survey periods: SeptemberDecember 1993, in the dry season and the beginning of the wet season; July-December 1994, during a severe dry season; and AprilJune 1995, at the end of the wet season, when most of the area was flooded. Navigation for all surveys was by topographical maps, global positioning systems and standard compasses.

The elusive nature and rarity of the Sumatran rhino makes direct observations difficult. Therefore, indirect methods were employed based on recording rhino sign, such as footprints, dung, scrapes and twisted saplings. In 1993 all prints were cast in wax (which sufficed for taking measurements and as evidence of our findings).

In 1994 measurements were taken in the field and in some cases the best prints were cast in gypsum. In 1994 the primary purpose of the authors was to obtain an estimate of the park's elephant population. This involved surveying $136 \mathrm{~km}$ of random, fixed-width 
transects (Figure 1). Between 15 and $49 \mathrm{~km}$ were surveyed separately in mature forest, young forest, swamp forest, scrub and alang alang, and between 2 than $6 \mathrm{~km}$ surveyed in swamp grass and swamp scrub (Reilly, unpubl. data).

In 1995 a brief presence/absence survey was carried out in the area from Kalibatin to Way Kanan, in order to assess the potential of this area as a permanent study site (after Wells and Franklin, 1994). This mainly forest habitat was surveyed following watercourses where possible to maximize the probability of finding rhino sign. No prints were found because much of the area was still flooded.

There is a limited window for surveying rhinos in Way Kambas. In the dry season the ground is hard and any prints are shallow and easily eroded. In the wet season fieldwork is difficult and prints are quickly washed away. The periods most suitable for surveying the elephant population appear to have been unsuitable for observing thino sign. Rhinos use an extensive networks of trails and following these would have furnished more rhino sign, particularly in 1994 when the use of fixedwidth transects limited visibility and the area covered in the survey. Therefore the quantity of rhino sign recorded and the suggested population estimate were likely to be low.

\section{Results}

The measurements of rhino prints recorded in Way Kambas from 1991 to 1994 and the cast (no. 9), made by the local PHPA park guards, of the rhino sighted by the Way Kanan river in 1991 are presented in Table 1. Some prints may have been superimposed, with the hind foot over the forefoot. The maximum print width was measured in all cases. The age of the prints was determined from the amount of debris in the print and information derived from any associated sign of rhino activity.

The age class of the rhino was derived from apportioning age classes to each parameter measured following Van Strien (1985). Front

Table 1. Measurements ( $\mathrm{mm}$, with minimum and maximum in parentheses) of rhino footprints in Way Kambas National Park

\begin{tabular}{|c|c|c|c|c|c|c|c|c|c|c|}
\hline $\begin{array}{l}\text { Print } \\
\text { no. }\end{array}$ & Date & PW & FHW & PL & $\begin{array}{l}\text { Age } \\
\text { class }\end{array}$ & $\begin{array}{l}\text { Sample } \\
\text { size }\end{array}$ & Substrate & $\begin{array}{l}\text { Print } \\
\text { age }\end{array}$ & Habitat & Location \\
\hline 1 & $\begin{array}{l}\text { Sept. } \\
1993\end{array}$ & $\begin{array}{l}196 \\
(188-200)\end{array}$ & $\begin{array}{l}66 \\
(63-69)\end{array}$ & 142 & $\mathrm{~J} / \mathrm{SA} / \mathrm{A}$ & $3 C$ & $\begin{array}{l}\text { Soft } \\
\text { streambed }\end{array}$ & Weeks & $\begin{array}{l}\text { Riverine } \\
\text { forest }\end{array}$ & Kalibatin \\
\hline 2 & $\begin{array}{l}\text { Oct. } \\
1993\end{array}$ & $\begin{array}{l}191 \\
(172-206)\end{array}$ & $\begin{array}{l}77 \\
(74-82)\end{array}$ & 154 & A & $4 \mathrm{C}, 2 \mathrm{~T}$ & $\begin{array}{l}\text { Dry } \\
\text { streambed }\end{array}$ & Weeks & $\begin{array}{l}\text { Mature } \\
\text { forest }\end{array}$ & $\begin{array}{l}\text { NW and } C \\
\text { Wako }\end{array}$ \\
\hline 3 & $\begin{array}{l}\text { Nov. } \\
1993\end{array}$ & $\begin{array}{l}190 \\
(178-211)\end{array}$ & $\begin{array}{l}67 \\
(61-77)\end{array}$ & 142 & $\mathrm{~J} / \mathrm{SA} / \mathrm{A}$ & $1 \mathrm{C}, 4 \mathrm{~T}$ & $\begin{array}{l}\text { Soft } \\
\text { pond bed }\end{array}$ & Weeks & $\begin{array}{l}\text { Mature } \\
\text { forest }\end{array}$ & E Kaliburu \\
\hline 4 & $\begin{array}{l}\text { Aug. } \\
1994\end{array}$ & 174 & 49 & 117 & $\mathrm{~J}$ & $1 \mathrm{~T}$ & $\begin{array}{l}\text { Dry } \\
\text { hard trail }\end{array}$ & Months & $\begin{array}{l}\text { Mature } \\
\text { forest }\end{array}$ & SE Wako \\
\hline 5 & $\begin{array}{l}\text { Aug } \\
1994\end{array}$ & 179 & 74 & 156 & $\mathrm{~J} / \mathrm{A}$ & $1 \mathrm{~T}$ & $\begin{array}{l}\text { Dry } \\
\text { clay trail }\end{array}$ & Weeks & $\begin{array}{l}\text { Mature } \\
\text { forest }\end{array}$ & SE Wako \\
\hline 6 & $\begin{array}{l}\text { Aug. } \\
1994\end{array}$ & 151 & 64 & 119 & $\mathrm{~J}$ & $1 \mathrm{~T}$ & $\begin{array}{l}\text { Dry } \\
\text { clay trail }\end{array}$ & Weeks & $\begin{array}{l}\text { Mature } \\
\text { forest }\end{array}$ & C Wako \\
\hline 7 & $\begin{array}{l}\text { Aug. } \\
1994\end{array}$ & 195 & 78 & 148 & $A$ & $1 T$ & $\begin{array}{l}\text { Dry } \\
\text { clay trail }\end{array}$ & Weeks & $\begin{array}{l}\text { Mature } \\
\text { forest }\end{array}$ & C. Wako \\
\hline 8 & $\begin{array}{l}\text { Aug. } \\
1994\end{array}$ & $\begin{array}{l}194 \\
(182-208)\end{array}$ & $\begin{array}{l}87 \\
(77-92)\end{array}$ & 176 & A & $4 \mathrm{~T}$ & $\begin{array}{l}\text { Clay } \\
\text { swamp forest }\end{array}$ & Days & $\begin{array}{l}\text { Mature } \\
\text { forest }\end{array}$ & NE Wako \\
\hline 9 & 1991 & 225 & 72 & 182 & A & $1 \mathrm{C}$ & River bank & Days & $\begin{array}{l}\text { Riverine } \\
\text { forest }\end{array}$ & $\begin{array}{l}\text { E Way } \\
\text { Kanan }\end{array}$ \\
\hline
\end{tabular}

PW, maximum print width; FHW, front hoof width; PL, print length.

A, adult; SA, subadult; J, juvenile.

$C$, measurements from cast; $T$, measurements of prints in the field.

(C) $1997 \mathrm{FFI}$, Oryx, 31 (2), 143-150 
hoof width is the parameter with least overlap among age classes, with a measurement of 71 $\mathrm{mm}$ or greater indicating an adult rhino (Van Strien, 1985). Prints 2, 5, 7 and 8 showed an overlap in the age classes as suggested by the three parameters measured (Table 1) and in these cases front hoof width was used to determine if the print was from an adult rhino.

The precision of assigning an age class based on print measurements is improved with large sample sizes, to account for variation within sets of prints arising from differences in substrate, gradient and age (Kurt, 1970 and Borner, 1979, in Van Strien, 1985; Flynn and Abdullah; 1983, Van Strien, 1985). Time and resource constraints made it impossible to obtain the suggested minimum of 10 casts from each series of prints in the field (Van Strien, 1985). Prints 1, 3 and 5 showed overlap in age classes with each parameter and were assigned no specific age class. Prints 6 and 7 from the same track, showed considerable variation in width. While it is difficult to draw conclusions from measurements of single prints, it is possible that these prints could represent a cow and calf pair.
Prints assigned to the same age class can be further differentiated if they are separated either spatially or temporally (Van Strien, 1985). Two assumptions are necessary if these criteria are to be applied to our findings. First, that the location of a print signifies the centre of a home range and, second, that rhinos have not moved and established new home ranges during the study. It is suggested that prints 2 , 7 and 8 are from the same adult rhino in Wako and that 9, and possibly 3, are from another adult rhino in Way Kanan/Kalibira. Prints 4 and 6 , and possibly 5, appear to be from the same juvenile in Wako, and 1 is from an individual rhino of undetermined age class in Kalibatin.

Differentiating prints and the rhinos that made them by this reasoning is problematic. Van Strien's study area was at a high elevation and mainly montane forest, whereas Way Kambas is low-lying with a mosaic of habitats. These substantial differences in vegetation, hydrology and topography could invalidate the $8 \mathrm{~km}$ suggested by Van Strien (1985) as sufficient to separate prints. It is also possible that some rhinos moved between years and

Table 2. Observations of rhino sign in Way Kambas National Park

\begin{tabular}{|c|c|c|c|c|c|c|c|c|}
\hline Date & Area & Dung & Urine & Browse & Marking* & $\begin{array}{l}\text { Twisted } \\
\text { * sapling }\end{array}$ & $\begin{array}{l}\text { Direct } \\
\text { obs. }\end{array}$ & Habitat \\
\hline Sept.-Oct. 1993 & West Kalibiru & 3 & - & - & - & - & - & Forest \\
\hline Sept. 1993 & Kalibatin & - & - & - & - & - & $\begin{array}{l}\text { Rhino } \\
\text { seen }\end{array}$ & $\mathrm{MF}$ \\
\hline Oct. 1993 & East Kalibiru & 1 & - & 1 & - & - & - & $\mathrm{MF}$ \\
\hline Oct. 1993 & South Wako & 20 & 1 & - & 7 & 5 & - & MF \\
\hline Oct. 1993 & Camp C & - & - & 1 & - & 1 & - & $\mathrm{Sc} \& \mathrm{MF}$ \\
\hline Nov. 1993 & Rawa Pasir & 1 & - & - & - & - & - & $\mathrm{SF}$ \\
\hline Aug. 1994 & Wako & 13 & 2 & 1. & 20 & 8 & - & MF,YF \& SF \\
\hline Sept. 1994 & Camp C & - & - & - & 2 & - & - & YF \& SF \\
\hline Sept. 1994 & Rawa Pasir & - & - & 1 & - & - & - & $\mathrm{YF}$ \\
\hline Sept.-Oct. 1994 & Kalibatin & - & 1 & 1 & 1 & 1 & - & MF \\
\hline Oct. 1994 & Ulung-ulung & 1 & - & - & - & - & - & MF \\
\hline Oct. 1994 & Kalibiru & - & - & - & - & - & $\begin{array}{l}\text { Rhino } \\
\text { heard }\end{array}$ & $Y F$ \\
\hline Apr. 1995 & Kalibatin & - & - & 1 & - & - & - & $\mathrm{MF}$ \\
\hline May 1995 & Rawa Pasir & 1 & - & - & - & - & - & SwSc \\
\hline 1993-1995 & Total & 40 & 4 & 6 & 30 & 15 & 2 & \\
\hline
\end{tabular}

MF, mature forest; YF, young forest; SF, swamp forest; Sc, scrub; SwSc, swamp scrub.

* Includes marking by rubbing, foot scrapes and horn scratches. 
seasons. Van Strien (1985) observed shifts in the home range of female and subadult rhinos and noted instances where home ranges exceeded the 8-km-diameter range size assumed to eliminate the possibility of overlap.

Table 2 presents all sign associated with rhino activity and any direct observations in chronological order from September 1993 to May 1995. The marking sign refers to rub marks, foot scrapes and horn scratches. Scrapes, usually at an oblique angle, were the most frequently recorded marking sign.

The greatest concentration of rhino sign was observed along the trail from camp D1 to Wako in both 1993 and 1994. Other areas, such as Ulung Ulung, Rawa Pasir, Kalibiru and Kalibatin were visited on regular surveys. In 1994 rhino sign was recorded only from five transects out of a total of 79. No recent signs of rhino were observed in the Kalibatin region during the 1995 survey; only potential but unused wallows were encountered.

Forty rhino dung piles were recorded and all contained characteristic $1-2-\mathrm{cm}$ twig particles. One intact dung bolus had a diameter of $14 \mathrm{~cm}$, which was well outside the usual range of $7-9 \mathrm{~cm}$ (Van Strien, 1985). In 1993 fresh urine (sprayed approximately $2 \mathrm{~m}$ high on vegetation) and more than 20 dung piles were observed along $4 \mathrm{~km}$ of the logging trail from camp D1 to Wako. In September 1993 three dung piles of varying ages were recorded at the same location in west Kalibiru, two dung piles overlapping and one approximately $5 \mathrm{~m}$ away. In October 1993 a fresh dung pile was observed further along this track. In general, dung was observed near other dung piles and recorded on old trails or along streams, in keeping with the findings of Van Strien (1985) and Borner (1979, in Van Strien, 1985).

Twisted saplings were encountered on seven occasions and are very distinctive examples of rhino presence (Borner, 1979 in Van Strien, 1985; Van Strien, 1985). Seven of the saplings were twisted at heights between 63 and $113 \mathrm{~cm}$ and had a diameter at breast height (d.b.h.) between 1.5 and $2 \mathrm{~cm}$. The combination of dung, urine and twisted saplings as observed on the main trail to Wako in 1994 are believed to be typical of adult male rhinos
(Flynn, 1978; Borner, 1979 in Van Strien; Van Strien, 1985).

Rhinos feed on undergrowth, leaves, herbaceous growth, shrubs and saplings (Van Strien, 1985). The results of a rhino survey in Endau Rompin, Malaysia, suggested that saplings constituted 98 per cent of a rhino's diet (Flynn, 1980 in Van Strien, 1985). In this study, rhino feeding was most clearly observed from signs of browsing on saplings. Three browsed saplings had a mean d.b.h. of $1.7( \pm 0.5) \mathrm{cm}$, and mean height where the sapling were pushed over of $65( \pm 1.2) \mathrm{cm}$. The mean density of saplings from 10 25-sq-m quadrats undertaken in 1993 showed that previously burnt secondary forest had 400 saplings per $25 \mathrm{sq} \mathrm{m}$, while logged secondary forest and scrub had approximately 200 saplings per $25 \mathrm{sq} \mathrm{m}$. The diversity of sapling species was greatest in logged forest with 46 species per $25 \mathrm{sq} \mathrm{m}$, followed by burnt forest with 35 and scrub with 11 species per $25 \mathrm{sq} \mathrm{m}$ (Reilly, unpubl. data).

No wallows were identified as being currently used. Possible rhino wallows were found close to print 7 in Wako and another three in the Kalibatin-Way Kanan area in 1995. These latter wallows were approximately $5 \times 5 \mathrm{~m}$ with raised back walls. Very old browsing sign was recorded close to one of these wallows.

Definite sightings of Sumatran rhinos were made in 1991 and 1993. The latter sighting, made along the main track into the park, is believed to have been of a large individual.

\section{Discussion}

Most rhino sign was recorded along game trails and old logging tracks. Only five records of rhino sign were noted from $136 \mathrm{~km}$ of transect surveyed in the park in 1994, suggesting that rhinos stray little from set routes. Out of the 15 separate observations of rhino sign, 13 were mainly in mature forest, indicating either that rhinos in Way Kambas use forest more than other habitats or that rhino sign is more easily observed in forest habitats (Table 2). Secondary forest had the greatest abundance 
and diversity of saplings, the main component of a rhino's diet (Flynn, 1980 in Van Strien, 1985). Approximately 50 per cent of the park is composed of mature and young forest as estimated from the vegetation map of Santiapillai and Suprahman (1986). This extent of suitable habitat could carry as many as 55 rhinos if one assumes a density of one rhino per $10 \mathrm{sq} \mathrm{km}$ as suggested by Van Strien (1985) for his montane study area. The findings from this study estimate a population of four individuals from Wako to Kalibatin with the further probability of more rhinos north of Wako. Recent reports indicate that this may be an underestimate (N. Van Strien, pers. comm.) The scarcity of prints was due in part to the difficulty of timing the surveys and aligning them with the requirements of the elephant study.

Van Strien's 5-year study is the most intensive and complete assessment of Sumatran rhino ecology to date and provides much information. However, there is difficulty in relating his findings (Van Strien, 1985) to the present study, given that the former was carried out in montane tropical forest, whereas the latter was carried out in low-lying coastal forest and grasslands. This difference in relief probably affects the size of home ranges. Another possible difference between these studies is the apparent lack of rhino wallows and salt licks in Way Kambas (Van Strien, 1985).

The frequency of wallowing noted by Van Strien (1985) suggests a need for rhinos to immerse themselves regularly. Unlike other rhino surveys elsewhere this study recorded no definite rhino wallows (Van Strien, 1985; Wells and Franklin, 1994). This is not typical but Van Strien noted that in flat areas along the Mamas River there were few wallows and rhinos probably used rivers, streams and peaty marshes to wallow. This suggests that rhinos in Way Kambas could use alternative wallowing sites in swampy areas and along watercourses.

No salt licks arising from natural springs were recorded. The artificial one at camp D2 may have been used by rhinos as indicated by rhino dung found nearby on separate days in 1993. Van Strien (1985) stated that salt licks are used regularly and have a considerable influence over behaviour, as evidenced by males frequenting salt licks with the intention of encountering females. As well as their influence on behaviour, salt licks provide minerals, although the importance of this for Sumatran rhinos remains unclear. In this respect rhinos in Way Kambas could probably use brackish water as an alternative mineral source. Brackish water is readily available and can penetrate some $20 \mathrm{~km}$ inland along the Way Kambas River (Wind et al., 1979). Sadjudin (1992), in his study of Javan rhinos in Ujung Kulon National Park, estimated that 80 per cent of rhinos concentrate in lowland areas and use the coastal areas to satisfy their salt requirements. If brackish water is used by the rhinos in place of saltlicks, it is unclear how this affects their social behaviour.

The observations of this study provide information on the status of the Sumatran rhino population in Way Kambas and prompt questions with respect to the rhino's ecology and behaviour. An intensive rhino survey based on the methodology in Wells and Franklin (1994) should be carried out to determine the structure of the rhino population in Way Kambas and investigate its ecology in lowland habitats.

\section{The status of Sumatran rhinos in Way Kambas}

Way Kambas is under pressure from development and human resettlement. Resettlement increased the human population in Lampung from 1.6 to 4.6 million between 1961 and 1980 (Scholz, 1983). The last rhino was believed to have been shot in Way Kambas in 1961 and Borner commented on the quantity of rifle shells he observed in the park (Borner, 1979 in Van Strien, 1985; Wind et al., 1979). Since these reports no pit traps or snares or any recent sign of poaching for rhino has been recorded in Way Kambas. Nevertheless, human disturbance in the park is considerable and was recorded from every area surveyed on nearly every day in the field.

The secondary forest of Plangijo, Way 
Kanan, Wako and some of the Kuala Kambas and Rasau resorts represents the park's most suitable rhino habitat but it is very accessible. The data suggest that Wako is a core area of rhino activity, with less rhino sign observed in camp C, Rawa Pasir, Ulung Ulung, Kalibiru and Kalibatin. It is believed that at least one rhino was active in Kalibatin in 1993 but follow up surveys in 1994 and 1995 revealed no sign of rhino activity there. This absence cannot be explained by the seasonal movements that Sumatran rhinos sometimes make (Van Strien, 1974) but is probably due to human disturbance. Van Strien (1985) stated that it is not unlikely that rhinos will leave areas where they are often disturbed by human presence.' However, two confirmed sightings of rhino in the park were made during daylight, along a busy river and by the main road into the park.

In general, most disturbance is caused by fishermen who sometimes use car batteries and insecticide to fish and often build fires to smoke their catches. The possibility of contamination is worrying not only for the rhino but also for other endangered species such as elephant, tiger Panthera tigris and white-winged wood duck Cairina scutulata. Fires used for smoking fish could get out of control and cause considerable damage, especially in the dry season. Further incursions into the park result from people foraging for garahu, a valuable fungal/tree derivative used in the perfume and incense industry. This is most common in the resorts of Susukan baru, Bungur and Rasau, where trees suspected to be infected with the fungus are felled with chain saws. Less common but more threatening to the rhino is deer hunting by parties using guns or dogs.

Antipoaching measures and the ease of access to the park need to be reviewed in order to combat disturbance and strengthen the protection of areas such as Wako. Therefore this study strongly advocates the PHVA workshop recommendation to intensify guard activity by increasing funding, training and equipment and to improve the efficient utilisation of forest guards and guard posts' (Soemarna et al., 1994). In addition, an awareness programme for local people would benefit all species, including the rhino, by highlighting the conservation importance of Way Kambas both nationally and internationally.

The situation in Way Kambas is unique, not least because a species of rhino presumed locally extinct has persisted and continues to survive. To this end the PHPA, the Indonesian Rhino Foundation and the International Rhino Foundation have come together to establish a Sumatran Rhino Sanctuary in Way Kambas. The Sumatran Rhino Sanctuary is a fenced restricted region of the park, which will house rhinos in near-natural, semicaptive conditions, with only limited management by humans. The core of the breeding population will consist of captive rhinos returned from zoos in Indonesia and several other zoos world-wide. These developments are supported by two dedicated rhino protection units from the UNDP Global Environment Fund Rhino Project, to provide better protection for what may very well be one of the better rhino populations left in Sumatra.

\section{Acknowledgements}

We are grateful for the generous support provided by Fauna \& Flora International, BirdLife International, the British Petroleum Conservation Awards, British Airways Environment Branch, the British Embassy to Indonesia, the British Ecological Society, the Royal Geographical Society and all the project sponsors. Particular thanks are due to the Indonesian Rhino Foundation (YMR); PHPA staff in Bogor, Tanjung Karang and Way Kambas, and Dr Marizal Ahmad and Dr Muhajir Utomo of the University of Lampung. We also thank the Way Kambas park guards and University of Lampung students who accompanied us into the field. Permission for the authors to work in Indonesia was kindly granted by the Indonesian Institute of Sciences (LIPI), PHPA and the University of Lampung. We are grateful to Dr Nico Van Strien, Dr Ciaran Kelly, Dr Martin Jones, Dr Haerudin Sadjudin, Dr Ken Irvine and an anonymous referee for helpful comments on the manuscript.

\section{References}

Soemarna, K., Tilson, R., Ramonn, W., Sinaga, D.W., Sukumar, R., Foose, T.J., Traylor-Holzer, K. and Seal, U. (eds). 1994. Sumatran Rhino in Indonesia. Population and Habitat Viability Analysis 
(PHVA) Report, Lampung, July 1994. IUCN/SSC CBSG, 1210 Johnny Cake Road, Apple Valley, MN 55124, USA.

Flynn, R.W. 1978. The Sumatran rhinoceros in the Endau Rompin National Park of peninsular Malaysia. Malayan naturalist, 4, (2), 5-12.

Flynn, R.W. and Abdullah, M.T. 1983. Distribution and number of Sumatran rhinoceros in the Endau Rompin region of peninsular Malaysia. Malayan Nature Journal, 36, 219-247.

Groombridge, B. (ed.). 1993. 1994 IUCN Red Data List of Threatened Animals. IUCN Gland, Switzerland and Cambridge, UK.

Khan, Mohd Khan bin Momin, Foose, T.J. and Van Strien, N.J. 1995. Chairman's Report, Asian Rhino Specialist Group. Pachyderm, 20, 1.

Sadjudin, H.R. 1992. Status and distribution of the Javan rhino Rhinoceros sondaicus, 1822, in Ujung Kulon National Park, West Java. Tropical Diversity, 1(1), 1-10.

Santiapillai, C. and Suprahman, H. 1986. The Ecology of the Elephant (Elephas maximus sumatranus L.) in the Way Kambas Game Reserve, Sumatra. Final report. Project 3133. WWF/IUCN, Bogor.

Scholz, U. 1983. The Natural Regions of Sumatra and their Agricultural Production Pattern. A Regional Analysis. Vol. 1, p. 257. Bogor, Indonesia. Central Research Institute for Food Crops.

Siswomartono, D., Reddy, S., Ramono, W., Manansang, J., Tilson, R., Franklin, N. and Foose, T. 1996. The Sumatran rhino in Way Kambas National Park, Sumatra, Indonesia. Pachyderm, 21, 12-13.
Van Strien, N.J. 1974. Dicerorhinus sumatrensis (Fischer), the Sumatran or two-horned Asiatic rhinoceros: a study of the literature. Mededelingen Landbouwhogeschool Wageningen, 74 (16), 82.

Van Strien, N.J. 1985. The Sumatran Rhinoceros Dicerorhinus sumatrensis Fischer 1814 in the Gunung Leuser National Park, Sumatra, Indonesia: Its Distribution, Ecology and Conservation. Private publication, Doorn, Holland.

Wells, P. and N. Franklin. 1994. Preliminary report of the current status of the Sumatran rhino in Bengkulu Region of Kerinci Seblat National Park. In Sumatran Rhino in Indonesia. Population and Habitat Viability Analysis (PHVA) Report, Lampung, July 1994 (eds K. Soemarna, R. Tilson, W. Ramono, D. W. Sinaga, R. Sukumar, T. J. Foose, K. Traylor-Holzer and U. Seal.

Wind, J., Djoko, S. and Waladi, I. 1979. Way Kambas Management Plan 1980-1985. FAO/INS/78/061, Report 5, Bogor.

Joanne Reilly, Conservation Research Group, Dept. of Biological Sciences, Manchester Metropolitan University, Manchester M1 5GD, UK.

Guy Hills Spedding, The Gables, Foxham, Chippenham, Wiltshire SM5 4NQ, UK.

Apriawan, Sub Balai KSDA, Taman Nasional Way Kambas, Way Jepara, Lampung Tengah 34196, Sumatra, Indonesia. 